\title{
CARE OF THE WOUNDED
}

SIR-My letter about " Care of the Wounded" (J. roy. Army med. Cps 121, 164) elicited a long letter from Bermuda in a firm black handwriting which many of my seniors would instantly recognise, and which many of us would do well to emulate. It was from Lieutenant-General Sir Alexander Hood, D.G.A.M.S. 1941 to 1948. I was delighted, and relieved, to find that he approved of much of what I wrote, but I think that readers of the Journal should be allowed to share some of his comments. He writes "All of us must agree that the object of a commander is to win battles, everything else is secondary to that--it is the contest of teeth $v$ tail; but there is one proviso which should be emphasised i.e. the consequences to the casualties if provision for them is necessarily inadequate. That should be fully understood by those who make final decisions. Failure to do that by medical planners, in my opinion, is why the medical services were the subject of Royal Commissions into their alleged failure in every major war from the Crimea up to and including the 1914 to 1918 war. I had these Royal Commission reports on a special table in my office from 1941 to 1946 and quoted from them frequently. Indeed the War Cabinet made the final decisions when they were fully informed on the possible consequences to casualties on the beeches, but we were lucky (that is another story) and hence no Royal Commission".

What an instructive picture-the great war-leader of our Corps with his 'special table ', like a notice warning skaters of thin ice. I am sure that there are some historical parallels. Dare I challenge you, Sir to produce one or two from your well-stocked fund of historical knowledge?

Another great war-leader acquitted our Corps of blame for failure of medical arrangements in our first campaign, as a Corps, the Sudan. In this fascinating book "The River War" Winston Churchill laid the blame on Kitchener; writing "The wounded Egyptian, and latterly even the wounded British soldier, failed to excite his sympathy". Strong words from a subaltern of 24 about the C in C; a nation's idol. A Lieutenant-Colonel R.A.M.C., later Lieutenant-General Sir Arthur Sloggett "Naughty Arthur" to my father's generation, was, in Winston's opinion," the most popular man in the force.

May I express the hope that this letter may stimulate Sir Alexander Hood to expand a little on "that is another story".

$$
\text { I am, etc., }
$$

\section{FRANK RICHARDSON}

10 Barnton Avenue West,

Edinburgh EH4 6DE.

10 October 1975

\section{SCUBA DIVING DURING PREGNANCY}

SIR-Diving with self-contained underwater apparatus (SCUBA), is a well-established sport both at home and abroad, and the Armed Services are careful to insist upon an effective standard both in the medical screening of newcomers to the sport and in the competence of instructors in sponsored clubs. 
Amateur diving is, of course, popular amongst young women and I should be interested to invite reader's experience with regard to the safety of underwater diving during pregnancy.

The doctor's advice to the young woman patient he is examining in anticipation of SCUBA activity, should naturally be dictated by caution, but there seems very little evidence of additional hazards attributable to a state of pregnancy. In fact, I understand that no animal experiments or human experience evidently indicate that diving is dangerous during pregnancy (Lundgren 1957).

The human body can withstand a desaturation stress in a ratio of about $2: 1$. That is, a person can ascend from a pressure of two atmospheres (a depth of 30 feet) to the surface (a pressure of one atmosphere), without risking the formation of nitrogen bubbles in the tissues. However, decompression tables which are calculated for depths greater than 30 feet allow no safety margin, and in fact, it is considered that an incidence of 3 per cent of minor decompression sickness is an acceptable risk.

Readers may be interested to note the recently published advice issued by the Undersea Medical Society, Inc: "the safety of SCUBA diving during the 1st trimester has not been established. Little is known about inert gas transport across the placenta. Until more information is available, diving deeper than 30 feet should be discouraged during pregnancy. The results of a nitrogen bubble developing in an ambryonic central nervous system, or a limb bud can only be surmized".

In view of inherent delay in the early recognition of pregnancy, one feels inclined to advise that SCUBA diving should be discouraged in any woman not practicing contraception. Such a criterion for screening holds the advantage of placing the consequent onus of safe diving practice upon the diver (where it properly belongs), and ensures that account is taken of the possibility of early pregnancy during the theoretically most vulnerable phase.

$$
\text { I am, etc., }
$$

\section{KENNETH H. HEDGES}

The International Nickel Company of Canada Ltd.,

Medical Director,

Copper Cliff, Ontario POM 1 NO.

22 Julv 1975.

\section{REFERENCES}

LuNDGren, C. (1975) The Medical School, Buffalo, N.Y., U.S.A. (personal communication).

Undersea Medical Society, Inc. (1975). "Pressure" Vol. 4, No. 1. 